\title{
ESTUDOS ORGANIZACIONAIS EM PERSPECTIVA
}

\section{Por Carlos Osmar Bertero}

Professor da FGV-EAESP

E-mail: cbertero@fgvsp.br

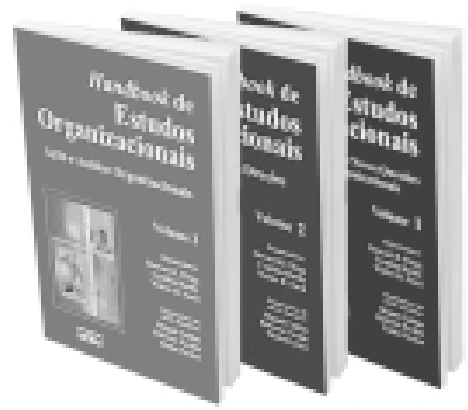

\section{HANDBOOK DE ESTUDOS ORGANIZACIONAIS}

De Stewart R. Clegg, Cynthia Hardy e Walter R. Nord (organizadores)

Miguel Caldas, Roberto Fachin e Tânia Fischer (organizadores da edição brasileira)

São Paulo: Editora Atlas, v. 1 (1999), v. 2 (2001), v. 3 (2004).
Esta obra ambiciosa na área organizacional, publicada originalmente em 1996, completa agora a sua versão em português com o lançamento do terceiro volume. A presente coletânea faz com que seja lembrado o Handbook of Organizations, organizado por James G. March, lançado em 1965. A despeito da associação, o Handbook de Estudos Organizacionais nunca se propôs ser uma atualização da obra pioneira de March. Diferentemente, os organizadores se propuseram desde 0 início produzir algo que se afastasse e criticasse o chamado mainstream - cujo campo é predominantemente ocupado por auto- res e obras norte-americanos -, de orientação teórica funcionalista e de metodologia preferencialmente neopositivista. Isso foi feito com convites a acadêmicos europeus, norte-americanos e australianos filiados a diversas abordagens. A edição brasileira ainda contém, ao final dos capítulos, notas técnicas escritas por autores brasileiros, que se detêm sobre as aplicações ou reflexões levantadas a partir do contexto nacional.

O editor brasileiro dividiu a obra original - publicada em apenas um volume - em três volumes. Os responsáveis pela organização da edição brasileira também alteraram a seqüência do texto original. Os volumes ficaram divididos da seguinte forma: o primeiro trata de "M odelos de análise e novas questões em Estudos Organizacionais"; o segundo aborda "Reflexões e novas direções"; e o terceiro, a "Ação e análise organizacionais". Os autores são reconhecidamente autoridades sobre os temas que exploram. Isso não excluiu inteiramente autores do mainstream, o que torna o livro aberto a divergências. Embora se propondo como alternativa crítica, a obra não deixa de colocar o leitor diante de posições e perspectivas oriundas das tendências predominantes na área. 
No primeiro volume, o capítulo de Michael Reed estabelece um amplo referencial, com o qual pretende cobrir todas as tendências do campo a partir de diversas abordagens. Mesmo em um campo tão complexo e multifacetado como o de Estudos Organizacionais, o resultado é bastante satisfatório. Seguese uma colocação de várias abordagens desenvolvidas nos últimos 25 , 30 anos, como ecologia populacional de organizações, institucionalismo, contingência estrutural e teoria crítica e pós-modernismo, este merecedor de um desdobramento, com um tratamento mais detido para cada um dos tópicos.

Das questões emergentes, talvez o capítulo sobre "Abordagens feministas em estudos organizacionais" seja o menos inovador, pois o assunto já vem sendo tratado há mais de três décadas, com razoável acúmulo de trabalhos. Os demais são realmente provocativos, como o capítulo sobre a diversidade, que carrega marca norte-americana, mas que deve incitar-nos a pensar no tema em outros contextos culturais, particularmente em um país como o nosso, onde a diversidade pode ser encontrada em abundância, seja etnicamente, seja do ponto de vista de diversidades regionais, ou de distâncias sociais entre classes e grupos. 0 volume conclui com o artigo de Gibson Burrell, que, pelo tema tratado, ficaria meIhor no terceiro volume, por tratar de questões sobre teorização e diversas abordagens da análise organizacional.

0 segundo e o terceiro volumes tratam de tópicos que são os mais estabelecidos na literatura, tais como estratégia, cultura, liderança, aprendizagem, poder, processo decisório e indivíduos em organizações. Há capítulos que tratam de questões ainda pouco abordadas pelo campo, como a tecnologia de informações e seu impacto e interface com os Estudos Organizacionais, e o excel ente capítulo sobre a abordagem estética da vida organizacional.

$N$ ão é possível em uma resenha tentar passar o conteúdo de um livro do porte, fôlego e diversidade de assuntos deste Handbook. Porém, cabem algumas observações e reflexões. A primeira reflexão é sobre o sentido de se produzir um texto como esse. Estudos menos ambiciosos têm adotado orientação análoga à do Handbook. Entre nós tem sido grande o número de trabal hos que vêm se acumulando em encontros acadêmicos como o Enanpad, e que fazem revisão de literatura e da produção científica brasileira, nas mais diversas áreas, inclusive na de organizações. Trata-se de uma preocupação em conhecer o desenvolvimento da área. Porém, el a é também reveladora de uma ansiedade para ver se estamos evoluindo ou nos repetindo ad infinitum. É também uma forma de fazer um balanço e de nos reassegurarmos de nossa situação.

A segunda reflexão refere-se à constatação de que muito se tem produzido e que o campo, se não chega a ter um padrão claro de acumulação, pelo menos se expande pela abertura de novos temas, abordagens e adoção de diversos referenciais teóricos. Bastaria comparar o conteúdo deste Handbook, de 1996, com o de James March, de 1965, e verificar o aumento de abordagens, tópicos discutidos, metodologias adotadas e, especialmente, a diversidade de referenciais teóricos. São exemplos dessa diversidade os matizes variados da abordagem crítica, o simbolismo organizacional, a abordagem cultural e a incorporação à análise organizacional de contribuições vindas da teoria econômica (teoria da firma, teoria dos custos de transação e teoria da agência). I sso leva à conclusão de que a área inegavel mente se enriqueceu.

A terceira reflexão refere-se ao aspecto pedagógico do texto. Embora não seja um resumo e de forma al guma se aproxime do que podemos chamar de' "manual", o Handbook é um instrumento para aqueles que atuam na área e aqueles que estão se inserindo nela. A sua leitura certamente permite que se avance e se aprofunde no conhecimento da área de forma mais sistemática. Também evita que os iniciantes se percam trilhando caminhos que já foram desbravados, alertando para as armadilhas e os equívocos mais comuns.

Para nós, latino-americanos e brasileiros em especial, cabe constatar que, apesar de nossa volumosa publicação na área de organizações, ainda não logramos inserção no campo. Afinal, o Handbook contém contribuições de acadêmicos de diversos países. $\mathrm{N}$ ão há brasileiros entre os autores nem há referência à produção brasileira. Alguns de nossos pesquisadores têm alcançado presença internacional em al gumas áreas, mas infelizmente ainda não em Estudos O rganizacionais.

Apesar do distanciamento de oito anos entre a publicação do texto original e a edição brasileira, 0 $H$ andbook continua sendo um texto cuja leitura é fundamental para que se possa obter uma visão da abrangência, da problemática e das dificuldades da área organizacional. Também fica a satisfação por se constatar que há muito para ser feito e que a área não dá mostras de exaustão. 